\title{
Patient's real necessity: perception of people with intestinal stomas about factors associated with complications
}

Necessidade real do doente: perceção de pessoas com ostomias intestinais sobre os fatores associados às complicaçóes

Necesidad real del paciente: percepción de las personas con estomas intestinales sobre los factores asociados a las complicaciones

Yterfania Soares Feitosa*(D); Luis Rafael Leite Sampaio**(D); Déborah Albuquerque Alves Moreira***iD;

Francisco Antonio da Cruz Mendonça**** (D); Tatyelle Bezerra Carvalho**** iD;

Thereza Maria Magalhães Moreira ${ }^{* * * * *}$ (D); Juliano Teixeira Moraes ${ }^{* * * * * * * \text { (D) }}$

\section{Abstract}

Background: The person with an intestinal stoma can develop complications that cause biopsychosocial impact. To know associated factors helps identify risks and develop an individualized care plan.

Objectives: To highlight the perception of people with stomas treated at the Health Care Service for People with Stoma (Serviço de Atenção à Saúde da Pessoa Ostomizada - SASPO) in Ceará, Brazil, about factors associated with complications in intestinal stomas.

Methodology: Descriptive, qualitative study performed with 65 participants with an intestinal stoma. Data gathered through structured interview, between April and June 2018, in the SASPO in Ceará, Brazil, and analyzed by the content analysis approach.

Results: Causalities attributed to ostomy and peristomal skin complications: skin changes related to collecting device; insufficient knowledge about self-care strategies and factors associated with complications; alterations associated with the effluent in contact with the skin; self-image disorder related to later complications and feelings related to the collecting device purchase process.

Conclusion: It is mandatory to develop prevention strategies to prepare professionals and patients regarding possible factors associated with complications.

Keywords: ostomy; complications; causality

\section{Resumo}

Enquadramento: A pessoa com ostomia intestinal pode desenvolver complicaçóes que acarretam impactos emocionais, físicos e socioeconómicos, sendo necessário conhecer os fatores associados para a construçáo do plano de cuidados.

Objetivo: Evidenciar as perceçóes de pessoas com ostomias, acompanhadas num Serviço de Atençáo à Saúde da Pessoa Ostomizada (SASPO), sobre fatores associados às complicaçóes em ostomias intestinais.

Metodologia: Estudo descritivo, qualitativo, realizado com 65 participantes com ostomias intestinais. Dados colhidos por meio de roteiro de entrevista estruturada, entre abril e junho de 2018, no SASPO no estado do Ceará, Brasil, e submetidos à técnica de análise de conteúdo.

Resultados: Causalidades atribuídas a alteraçóes da pele relacionadas com o equipamento coletor; conhecimento insuficiente sobre as estratégias de autocuidado; conhecimento insuficiente sobre fatores associados às complicaçôes; alteraçôes relacionadas com o contacto do efluente com a pele; distúrbio de autoimagem relacionado com as complicaçóes tardias; e sentimentos relacionados com o processo de compra dos equipamentos coletores.

Conclusáo: É necessário o desenvolvimento de estratégias preventivas para a preparação de profissionais e pacientes sobre fatores associados às complicaçóes das ostomias.

Palavras-chave: ostomia; complicaçóes; causalidade

*MSc., RN, University of Fortaleza, 60811-905, Fortaleza, Brazil [yterfania@yahoo.com.br]. (D) https://orcid.org/0000-0002-6021-7557. Contribution to the article: data collection, article witing **Ph.D. Lecturer, Regional University of Cariri, 63105-010, Crato, Brazil [rafael.sampaio@ urca.br]. (D https://orcid.org/0000-0003-1437-9421. Contribution to the article: orientation of all research stages, critical review and final writing of the article. Address for correspondence: Rua Cel. Antônio Luis, 1161 - 63105-000 - Pimenta - Crato/CE, Brasil.

***:Postgrad, RN, Regional University of Cariri, 63105-010, Crato Brazil [deboraah.allb querque@outlook.com]. (10 https://orcid.org/0000-0002-2823-8681. Contribution to the article: article writing

****:Ph. D. RN University Centre of Estácio do Ceará, 60810-270, Fortaleza Brazil [mendoncafac@hotmail.com].D https://orcid.org/0000-0002-3957-7048. Contribution to the

article: article revision. hotmail.com]. (D) https://orcid.org/0000-0001-6515-7963. Contribution to the article: a ticle writing and adaptation to the journal guidelines.

******Ph.D., RN, University Centre of Estácio do Ceará, 60810-270, Fortaleza, Brazil [thereza.moreira@uece.br]. (D) https://orcid.org/0000-0003-1424-0649. Contribution to the article: article revision.

*******Ph.D., RN, Federal University of São João Del-Rei, 36307-352. Minas Gerais, Brasil julianotmoraes@ufsiedu.br]._D https://orcid.org/0000-0002-1109-962X.Contribution to the article: article revision

\section{Resumen}

Marco contextual: La persona con estoma intestinal puede desarrollar complicaciones que causan impactos emocionales, físicos y socioeconómicos, por lo que es necesario conocer los factores asociados para construir un plan de atención.

Objetivo: Destacar las percepciones de las personas con estomas, monitorizadas en un Servicio de Atención Sanitaria de la Persona Ostomizada (Serviço de Atençáo à Saúde da Pessoa Ostomizada - SASPO), sobre los factores asociados a las complicaciones de los estomas intestinales.

Metodología: Estudio descriptivo y cualitativo realizado con 65 participantes con estomas intestinales. Los datos se recogieron a través de un guion de entrevista estructurada, entre abril y junio de 2018, en el SASPO en el estado de Ceará, Brasil, y se sometieron a la técnica de análisis de contenido.

Resultados: Las causas atribuidas fueron alteraciones de la piel relacionadas con el equipo colector; conocimiento insuficiente de las estrategias de autocuidado; conocimiento insuficiente de los factores asociados con las complicaciones; alteraciones relacionadas con el contacto del efluente con la piel; trastorno de la autoimagen relacionado con complicaciones tardías, y sentimientos relacionados con el proceso de compra de los equipos colectores.

Conclusión: Es necesario desarrollar estrategias preventivas para preparar a profesionales y pacientes en torno a los factores asociados a las complicaciones de los estomas.

Palabras clave: ostomía; complicaciones; causalidad 


\section{Introduction}

The creation of an ostomy is a condition that affects people of all ages, regardless of gender, race, and social condition. It is a surgical procedure that seeks to connect, temporarily or permanently, a hollow organ to an external medium, through an opening in the abdominal wall (Freitas, Borges, \& Bodevan, 2018).

Intestinal ostomy surgery, to deviate intestinal flow to a collection bag, causes changes in physiology as well as changes in lifestyle and individuals' physical and psychosocial features (Mota, Gomes, \& Petuco, 2016).

When done with the appropriate surgical technique, preceded by the correct pre-op marking on the ostomy site, in an area that guarantees adhesiveness of the device and easily seen by the patient, it is possible to reduce the rate of post-op complications such as necrosis, ischemia, retraction, stenosis, parastomal hernia, abscess, and dermatitis (Jayarajah, Samarasekara, \& Samarasekera, 2016).

The process of adaptation and learning how to care for the stoma is time-consuming, laborious, and stressful for patients and their families. All are affected differently and go through a process of grief that makes it hard to learn and adapt, especially in the first months after the ostomy (Sena, Nascimento, Sousa, Oliveira, \& Maia, 2017). Among the adversities that may hurt the daily life of these individuals, complications from the ostomy or on the peristomal skin are currently a challenge to the health team, patients, and their families. Thus, knowing the factors associated with the emergence of complications helps to identify risk factors and to build an individualized care plan.

A retrospective study, completed in 2015 with 572 patients cared for by the Association of Ostomy Persons of Rio Grande do Norte (Associação dos Ostomizados do Rio Grande do Norte - AORN), showed that a third of the interviewees presented ostomy-related complications, the most common being dermatitis, prolapse, and parastomal hernia. The causes have multifactorial origins and may be related to factors like age, location, obesity, effluent, inadequate management of the collection device, length of time, and frequency of exchange, among others (Santos \& Cesaretti, 2015).

Considering this scenario, this research aimed to identify the main complications in intestinal ostomies, due to the importance of expanding the discussions regarding this issue, in light of the emotional, physical, and socio-economic impact caused by ostomy complications.

In light of the above, this study sought to confirm the perceptions of people with a stoma, cared for at the Health Care Service for People with Stoma (Serviço de Atenção à Saúde da Pessoa Ostomizada-SASPO), in the state of Ceará (Estado do Ceará-CE), Brazil, regarding factors associated with complications from intestinal ostomies.

\section{Background}

Ostomy-related complications may be classified as early (bleeding, edema, infection, peristomal dermatitis, retraction, ischemia, or external flap necrosis) or late (stenosis, obstruction, prolapse, parastomal hernia, and fistulas). Among the systemic changes, there are hydroelectric disturbances in ostomies that have high output and anemia, in situations when there is hemorrhage of varicose veins located at the ostomy. In temporary ostomies, there may also be morbimortality related to the closing (Santos \& Cesaretti, 2015). In a study completed in northeastern Brazil, with the participation of ostomy individuals, the main reported complications were dermatitis in the peristomal site, whose causalities were stoma retraction, perforation, or poor device adaptation, mechanical trauma, abrasion, allergic reactions to the material in the collection device or adjuvants (Feitosa et al., 2018).

Complications may, however, be avoided by planning the location of the ostomy site and using an appropriate surgical technique (Miguel, Jiménez, \& Parajó, 2014). Marking the ostomy consists of marking the boundaries of the site, which can be done by stomal therapy nurses, in order to enhance, during the surgery, the ability to adapt to the effluent collection device, all with a minimum of discomfort for the patient (Pengelly et al., 2014).

Following the standard procedure for stoma placement significantly reduces the rate of complications, guaranteeing adhesiveness of the device and good visibility by the person with a stoma and creating a strategy for preventing complications like stenosis, prolapse, ostomy retraction, and ischemia (Forsmo et al., 2016). 
Besides physical complications, intestinal ostomies change the physical appearance, and bodily function of people, the externalization in the abdomen creates significant changes in how these individuals see themselves and where they may feel anxious or self-conscious, altering their social and family roles (Sena et al., 2017). Another change that comes from the ostomy is the change in the person's social role in the family and society. There may be a difficulty of occupational reintegration, caused by loss or limitation of productive capacity. These problems may be a result of insecurity due to the quality of materials or device used (Mota et al., 2016). In light of this, the importance of a systematized nursing service should be highlighted, at an outpatient level, explicitly oriented to the humanized care of patients in the pre-op phase, ensuring follow-up through the clinical evaluation and the behaviors that each situation requires. It becomes necessary to have a therapy plan that encompasses the different treatment phases, from pre-op to surgery and post-op (Lima, 2017).

\section{Research question}

What are the perceptions of people with ostomies, cared for by SASPO, regarding factors associated with ostomy complications?

\section{Methodology}

Initially, authorization was requested from SASPO in Ceará, Brazil, to carry out the study in the city of Fortaleza. Two hundred eighty-seven patients with intestinal stoma are registered at SASPO, 115 (40\%) of whom showed some complication with the ostomy or peristomal skin. Of these, and according to the criteria of theoretical saturation, 61 people with a permanent intestinal stoma were interviewed, based on the criteria for inclusion in the study.

Those included were people with an intestinal stoma, over 18 years old, of both genders, who chose to participate in the research and who signed the free and informed consent form and who appeared at the health services during the data gathering period. People with any cognitive disability that would inhibit their ability to answer the questions were excluded.
Later, the participants were informed regarding the objective of the study and told that all information provided would be kept confidential. Participation in the study was voluntary, with a signed free and informed consent form (Termo de Consentimento Livre e Esclarecido TCLE), based on the Resolution of the $\mathrm{Na}$ tional Health Council 466/12, approved by the Research Ethics Committee at the University of Fortaleza (Comissão de Ética em Pesquisa da Universidade de Fortaleza - UNIFOR), under opinion no. 2.542.686 and Certificate of Presentation for Ethical Assessment (CAAE) no. 83103518.4.0000.5052.

This is a descriptive, qualitative study, with data collected using an interview script that was created and adapted by SASPO in Ceará, Brazil, focusing on a leading question related to the causality of complications in the intestinal ostomy. The study was carried out between April and June 2018, at SASPO, in the municipality of Fortaleza - CE, Brazil, which cares for patients from this municipality and is a benchmark for the 184 municipalities of the state of Ceará.

The interviews were recorded, with prior authorization from the participants, and later transcribed in full and coded with the letter $\mathrm{E}$ and an Arabic numeral (E01,...E61), matching the order of the interviewees.

The data analysis was carried out using the Bardin content analysis method, a methodology process that can be applied to various speeches and forms of communication (Bardin, 2011). It was followed by the stages of pre-analysis, exploration of material and handling results, inference and interpretation. Content analysis is a methodology that seeks to analyze different forms of communication, verbal or non-verbal, gathered in interviews or direct observation, material which was extracted after detailed and exhaustive analysis and then classified/separated into themes or categories (Silva \& Fossá, 2015). The authors declare that there are no political and/or financial conflicts of interest related to the materials provided and used in this study, nor was any funding received for its completion.

\section{Results and Discussion}

In light of the difficulties experienced by the interviewees and the changes imposed by the 
intestinal ostomy, after a systematic reading of responses, the following categories emerged: skin changes related to collecting device; insufficient knowledge about self-care strategies and factors associated with complications; alterations associated with the effluent in contact with the skin; self-image disorder related to later complications and feelings related to the collecting device purchase process.

\section{Skin changes related to collecting device}

This category focuses on the participants' perceptions of changes in the peristomal skin caused by the collecting device. The responses showed the dissatisfaction of some of the interviewees regarding the adhesiveness of the bag provided by the service: "because there are some good bags. Some hold four days; others start to loosen after two days; it's difficult, and it's bad because it burns and irritates our skin" (E60; June 2018);

That bag with the adhesive around it, it sticks to the skin, it itches so much it hurts. Right now, I am sore because I got one of those bags from here, but I returned it because I only use bags without the adhesive around the edge. (E45; June 2018)

The statements described the difficulties faced by some participants regarding adaptation to the collection device, claiming that dermatitis appearing on the peristomal skin could be related to the quality of the material procured by the municipality. In these cases, the compromised cutaneous area generally has the shape of the area that is in contact with the device, however, it is necessary to evaluate, with the patient, the method of self-care the patient used, which would, in turn, foster better adaptation of the ostomy bag and avoid complications related to improper use of the device (Santos \& Cesaretti, 2015).

The peristomal skin is continuously exposed to various substances, including the collection device and adjuvants, which can cause abrasions, infections, and contact dermatitis. Although rarely related, when present, allergic contact dermatitis (dermatite alérgica de contacto - DAC) is commonly related to the use of products intended for peristomal skincare. However, the disturbing aspect of these products is not well known, and there are no large-scale studies on this topic (Cressey et al., 2016).
A retrospective study carried out by Cressy et al. (2016) between January 2010 and March 2014, with 18 patients at four university hospitals in New York City, all with peristomal dermatitis, showed that the emergence of complications was directly related to the use of adjuvants used in peristomal skincare. According to the authors, the frequency of peristomal contact dermatitis was 14/18 (77.7\%); however, what has not been determined yet is the specific chemical composition of the agents responsible for causing that type of reaction.

Therefore, it is essential to establish the need for skin sensitivity tests by professionals involved in this process, during selection of the device and/or adjuvants used in the care of the person with stoma, since, if appropriate choices are made, that measure could potentially prevent allergic dermatitis (Santos \& Cesaretti, 2015). For some of the interviewees, poor adaptation to the collection device may be related to the specific type of bag: "It's when I change bags. That's when I get an irritation, little blisters, but there is a bag that I really like and that does not cause an irritation" (E61; June 2018); "there is a type of bag, that bigger one, that hurts and causes a water blister" (E43; June 2018); "It was the one-piece bag that irritated the skin; it turned red and was full of bumps/ welts" (E54; June 2018).

Each patient requires different care and a different device and, in order for this to happen, it is essential to know the user's profile to orient the care and to plan for human resources and materials. Therefore, choosing the right bag must take into consideration basic requirements for its selection: safety, protection, efficacy of collecting waste, ease of use, and comfort (Collet, Silva, \& Aymone, 2016).

The National Health Policy for the Person with Disabilities, instituted by order no. 400/09 of 16 November 2009, by the Brazilian Ministry of Health, establishes that instructions regarding self-care and the choice of collection devices and adjuvants must include specialized interdisciplinary care, with the goal of rehabilitation and an emphasis on preventing complications (Portaria no 400/09 de 16 de novembro de 2009, Diário Oficial da União no 220/09. Ministério da Saúde, Secretaria de Atenção à Saúde).

Within this context, the health team fulfills an 
essential role in choosing the appropriate device, since it is up to these professionals to guide the advantages and disadvantages of each device, depending on the individual characteristics of each patient and on personal choice, particularly when these gain experience with self-care (Mota et al., 2016).

\section{Insufficient knowledge about self-care strategies} This category covers interviewees' knowledge of self-care strategies, essential in maintaining the integrity of the skin.

We do not have much experience, and we would change the bag three times, the skin would get irritated, the bag would not attach, but now it's better because I watched some online videos that explained that the skin should be really dry. (E23; May 2018)

"Due to lack of hygiene, the skin became irritated" (E59; June 2018). The previous responses showed that the participants understood the connection between the emergence of complications and the lack of knowledge regarding ostomy care. During analysis, it was clear that some interviewees had questions regarding the frequency of changing the device and care of the peristomal skin.

For Araujo, Braz, and Trandafilov (2017), teaching self-care should start when the medical treatment is decided, emphasizing that education should be gradual so that the patient can better assimilate the information received, starting at the pre-op phase.

From this perspective, it is recommended that eligibility for self-care must be implemented based on the development of the patient's and family members' skills, so that they can be empowered and independent in making decisions regarding ostomy care (Crepalde, 2016).

Another study shows the importance of the nurse's role in promoting health in this situation, facilitating the learning process for patients and their family/caregivers, developing strategies for learning self-care and providing for and contributing to the patient's autonomy (Mota et al., 2016).

\section{Insufficient knowledge about factors asso- ciated with complications}

In the following excerpts it was observed that, when asked about the possible reasons that they believe could be associated with the appearance of complications related to the ostomy and/ or peristomal skin, some interviewees were not able to attribute it to anything specific: "I don't know what caused the problem" (E01; April 2018); "I have no idea. I don't know what burned the skin around it" (E10; April de 2018).

In light of these answers, it was determined there is a lack of understanding by some of the participants regarding risk factors of complications related to the ostomy and/or peristomal skin. Therefore, it is essential to understand that several factors could lead to complications, such as low income and education, type of underlying disease, inadequacies in the teaching-learning process between professional and patient or other subjective issues, not always communicated by patients (Araujo et al., 2017). The more aware of their condition and their role as participants in this process, the more apt patients are to actively exercise their individuality, based on personal choices (Santos \& Cesaretti, 2015).

Within this context, nurses fulfill a crucial role during the time they share teaching-learning strategies, seeking to ensure the development of skills that promote self-care and sharing of experiences, in an attempt to develop a care plan that is individualized and congruent with the user's real needs (Araujo et al., 2017).

In this way, the development of strategies for teaching self-care must be understood as a partnership between the professional, the patient and the caregiver, taking into consideration that which the patient identifies as a need, based on daily observation of the patient and family members. The patient's interests and needs are essential for building and providing tools (brochures, multimedia programs, among others) for productive educational activities (Mota et al., 2016).

\section{Alterations associated with the effluent in contact with the skin}

Information gathered from interviews showed that some participants related alterations with effluent contact and peristomal skin: "It becomes irritated when the liquid touches the skin. It becomes very irritated, so much that sometimes the bag will not stay attached. Half an hour goes by, sometimes two days, and the 
bag will fall off” (E11; April 2018); "That irritation that is on the skin, a type of burn, I believe is from the liquid that leaves the intestine, I call it gastric juice" (E12; April 2018).

Contact of the effluent with the skin is one of the most significant risk factors for dermatological complications, occurring primarily in ostomies without the appropriate projection of the intestinal loop in the abdominal wall. The peri-ileostomy skin is the most frequent location of this complication, since the ileal conduit has the highest frequency of elimination and has an alkaline $\mathrm{pH}$, rich in proteolytic enzymes that, when in contact with the peristomal skin, causes irritant dermatitis, leads to a loss of cutaneous integrity, triggering an inflammatory process that may lead to erythema, skin erosion, hemorrhaging points, and pain (Santos \& Cesaretti, 2015).

When associated with other factors, irritant dermatitis, caused by the effluent, may result in a cycle of skin deterioration, from a decrease in adhesiveness of the collecting device to intestinal content leakage. Thus, the small cut-out of the hole in the protective barrier exposes the peristomal skin to the effluent (Araujo et al., 2017). Therefore, the professional nurse acts as a facilitator in the process of the patient accepting the new way of eliminating effluents and teaches the patient to recognize the signs of complications, promoting the development of self-care (Farias, Nery, \& Santana, 2019).

\section{Self-image disorder related to later compli- cations}

This category is made up of responses that suggest the appearance of delayed complications.

Fifteen days after my colostomy, edema appeared, evolving over a few days until we realized that the development was not normal. It was huge, so we returned to where I had the procedure... where we were told that the procedure would have to be redone because it was prolapsed. (E08; April 2018)

Two months after my operation, there was a complication with the bag. I had no bowel movements; everything was stopped. I had to return to the hospital and have another operation. The stoma was opened, and a colon loop was brought up. (E57; June 2018)

Digestive ostomies are subject to complications that may occur either immediately, after the surgical procedure (early or immediate complications), or some months later (delayed complications). While the first are frequently tied to emergency surgeries, when there is no prior planning for their execution, the latter are generally related to the illness that led to the ostomy (Santos e Cesaretti, 2015).

Among the delayed complications most commonly cited in the literature, the following stand out: stenosis, obstructions, prolapse, hernia, fistulas, and peristomal dermatitis (Santos \& Cesaretti, 2015). During the interviews, there were recurring reports of prolapse, one of the more common complications in intestinal ostomies, where a section of the intestinal loop exits the ostomy opening. Among the risk factors for its occurrence are large openings in the abdominal wall, inadequate attachment of the intestine on the abdominal wall, increase in abdominal pressure in post-op, and obesity, among others (Lima, 2017). In this sense, it should be noted that follow-up, directions, and professional care are essential in educating the patient about the risks caused due to weight gain or intra-abdominal pressure, about the appearance of possible changes resulting from the surgical procedure, allowing the individual to be able to make an early identification of those signs, thus avoiding the appearance of complications during the post-op period (Araujo et al., 2017). On the other hand, stenosis, as cited by a participant, is characterized by a narrowing of the stoma or its lumen, which, although well-tolerated by most patients, may cause obstructive episodes due to fecal impaction. In these cases, dietary measures may be implemented to avoid constipation. Colonic irrigations may also be useful, as well as laparotomy or laparoscopic reconstruction as a last resort (Santos \& Cesaretti, 2015).

\section{Feelings related to the collecting device pur- chase process.}

This category focuses on the negative perceptions of a few participants regarding the dispensing of collecting devices and the failure to account for the individuality of patients with ostomies during the process of distribution of materials by the health services.

The biggest problem lies in the ostomy bag offer because sometimes one bids on and wins a contest of bad bags. I don't know how that all works, but the patients are the ultimate losers because when we use a poor-quality bag, the bag site becomes 
irritated and we're powerless to do anything. We can complain and talk about it, but we can't change it, and so we're forced to use the bag with the worst quality and different model. Each person that goes through that type of surgery has a model of bag to use and, most times, I use the one that is available at the health center. You have no bargaining power, no ability to get the bag that meets your needs. That, in my opinion, is the greatest problem. The patient's real needs must be taken into consideration. (E05; April 2018)

As one can see, the previous statement showed feelings of dissatisfaction, frustration, and helplessness regarding how devices are offered. It also showed the difficulty some patients have in adapting to the collection devices provided, which, many times, are not adapted to the individual needs of the interviewees, thus resulting in local complications like irritations. Furthermore, it contradicts the Public Health System's principle of participation and social control.

In addition to reaffirming the assumptions of the Health Reform regarding the universal right to health and the responsibility of the State, the National Policy of Strategic and Participative Management, instituted by Ministerial Order GM/MS no. 3.027, of 26 November 2007 , highlights not only the appreciation for the different methods of public participation and social control in the management processes of the Public Health System, but it also focuses on the social inclusion of specific groups, like individuals with ostomy, seeking equality in the right to health (Ministério da Saúde. Secretaria de Gestão Estratégica e Participativa, 2009). The biggest challenge is not adjusting the quality of the device, but rather adjusting the type of device to each individual, a right guaranteed by Ministerial Order no. 400/09 and by the International Ostomy Association, which, in its Charter of Ostomates' Rights, seeks, among other things, to guarantee the unrestricted access to a variety of ostomy products accessible on the market (Portaria n. ${ }^{\circ} 400$ de 16 de novembro de 2009, Diário Oficial da União n. ${ }^{\circ}$ 220/09, Ministério da Saúde, Secretaria de Atenção à Saúde; Ministério da Saúde. Secretaria de Gestão Estratégica e Participativa, 2009; Hey \& Nascimento, 2017).
Therefore, factors like how the public notice is drawn up for the tender process, the process itself, the large number of brands and specifications of devices on the market, and the characteristics of each region jointly contribute to the inadequate distribution of those devices, according to the needs of each individual (Hey \& Nascimento, 2017).

In light of this, considering the variety of collection devices and adjuvants available for the care of ostomy patients, the political and social role of managers in this process is essential to guarantee the provision of materials that are adequate to the needs of each patient and the preservation of these individuals' autonomy.

The authors point out that the study was limited by the difficulty of access to ostomy patients because, at SASPO, the collecting device was occasionally provided to the caregiver, and by the difficulties of the professional in giving selfcare guidance and developing an individualized and personalized care plan.

\section{Conclusion}

Based on the categories presented, it is evident that irritant contact dermatitis is generally the most common complication seen in patients receiving care at SASPO in the municipality of Fortaleza, Ceará, Brazil, whether related to collecting devices, the patients' insufficient knowledge of self-care strategies, and/or factors associated with the development of complications, the contact of the effluent with the skin, the surgical procedure, or the process of purchasing collection devices.

The empirical data analysis regarding the perception of people with a stoma receiving care at SASPO in the state of Ceará, Brazil, regarding factors associated with an ostomy and peristomal skin complications, showed the real needs of individuals with intestinal ostomies.

Additionally, there was a prevalence of responses that focused on the negative aspects of collection devices provided by the health services, which, according to participants, did not take into consideration the needs of each patient when providing the collection material.

Therefore, the authors hope that the results presented in this study may strengthen the strategies for promoting care, planning assistance, 
and preventing ostomy-related complications, to enable a continual search for the establishment of patient rights and an improvement in their quality of life.

\section{References}

Araujo, R., Braz, D., \& Trandafilov, A. (2017). A importância das orientaçóes de enfermagem para doente. Revista Pesquisa e Ação, 3, 1-13. Retrieved from https://revistas. brazcubas.br/index.php/pesquisa/article/view/270/413

Bardin, L. (2011). Análise de conteúdo. São Paulo, Brasil: Edições 70.

Collet, J. A., Silva, F. P., \& Aymone, J. L. (2016). Bolsas coletoras utilizadas por estomizados: Uma análise tridimensional. Design \& Tecnologia, 6(11), 1-10. Retrieved from https://lume.ufrgs.br/handle/10183/151143

Crepalde, P. A. (2016) Características sociodemográficas e clinicas que afetam a qualidade de vida em doentes estomizados intestinais (Master's dissertation). Universidade Estadual Paulista, Brasil. Retrieved from https://repositorio.unesp. br/handle/11449/138111

Cressey, B. D., Belum, V. R., Scheinman, P., Silvestri, D., McEntee, N., Livingston, V., ... Zippin, J. H. (2016). Stoma care products represent a common and previously underreported source of peristomal contact dermatitis. Contact Dermatitis, 76(1), 27-33. doi:10.1111/cod.12678

Farias, D. L., Nery, R. N., \& Santana, M. E. (2019). O enfermeiro como educador em saúde da pessoa estomizada com câncer colorretal. Enfermagem em Foco, 10(1), 35-39. Retrieved from http://revista.cofen.gov.br/index. php/enfermagem/article/view/1486/490

Feitosa, Y. S., Sampaio, L. R., Moreira, D. A., Mendonça, F. A., Viana, M. C., Sacramento, K. P., ... Galdino, Y. L. (2018). Meanings attributed to complications of ostomy and skin peristhectomy in a public reference service in the Cariri region. Estima: Brazilian Journal of Enterostomal Therapy, 16, e3918. doi:10.30886/estima.v16.651_IN

Forsmo, H. M., Pfeffer, F., Rasdal, A., Sintonen, H., Körner, H., \& Erichsen, C. (2016). Pre and postoperative stoma education and guidance within an enhanced recovery after surgery (ERAS) programme reduces length of hospital stay in colorectal surgery. International Journal of Surgery, 36(1), 121-126. doi:10.1016/j.ijsu.2016.10.031

Freitas, J. P., Borges, E. L., \& Bodevan, E. C. (2018). Caracterização da clientela e avaliação de serviço de atenção à saúde da pessoa com estomia de eliminação. Estima: Brazilian Journal of Enterostomal Therapy, 16, 1-10. doi: 10.30886/estima.v16.402_PT
Hey, A. P., \& Nascimento, L. A. (2017). A pessoa com estomia e o fornecimento de equipamentos coletores e adjuvantes pelo Sistema Único de Saúde. Estima: Brazilian Journal of Enterostomal Therapy, 15, 92-99. doi:10.5327/Z1806-3144201700020005

Jayarajah, U., Samarasekara, A. M., \& Samarasekera, D. N. (2016). A study of long-term complications associated with enteral ostomy and their contributory factors. BMC Research Notes, 9, 1-6. doi:10.1186/s13104-016-2304-z

Lima, S. G. (2017). Complicaçôes em estomas intestinais e urinários: Revisão integrativa (Master’s dissertation). Retrieved from https://repositorio.unesp.br/handle/11449/150170

Miguel, V. M., Jiménez, E. F., \& Parajó, C. A. (2014). Current status of the prevention and treatment of stoma complications. A narrative review. Cirugia Española, 92(3), 149-56. doi:10.1016/j.cireng.2013.09.021

Ministério da Saúde. Secretaria de Gestão Estratégica e Participativa. (2009). Politica nacional de gestão estratégica e participativa no SUS -: ParticipaSUS. Brasília. Brazil: Author. Retrieved from http://bvsms.saude.gov.br/bvs/ publicacoes/politica_estrategica_participasus_2ed.pdf

Mota, M. S., Gomes, G. C., \& Petuco, V. M. (2016). Repercussóes no processo de viver da pessoa com estoma. Texto Contexto Enfermagem, 25(1), e1260014. doi:10.1590/0104-070720160001260014

Pengelly, S., Reader, J., Jones, A., Roper, K., Douie, W. J., \& Lambert, A. W. (2014). Methods for siting emergency stomas in the absence of a stoma therapist. Annals of the Royal College of Surgeons of England, 96(3), 216-218. doi: 10.1308/003588414X13814021679717

Portaria n. 400 de 16 de novembro de 2009. Diário Oficial da União no 220/09. Ministério da Saúde, Secretaria de Atenção à Saúde. Brasília, Brasil. Retrieved from http://bvsms.saude.gov.br/bvs/saudelegis/sas/2009/ prt0400_16_11_2009.html

Santos, V. L., \& Cesaretti, I. U. (2015). Assistência em Estomaterapia: Cuidando de pessoas com estomia. Rio de Janeiro, Brasil: Atheneu.

Sena, R. M., Nascimento, E. G., Sousa, W. P., Oliveira, M. A., \& Maia, E. M. (2017). Aspectos emocionais do indivíduo no enfrentamento da condição de estomizado. Estima: Brazilian Journal of Enterostomal Therapy, 15(1), 43-49. doi:10.5327/Z1806-3144201700010007

Silva, A. H. \& Fossá, M. I. (2015). Análise de conteúdo: Exemplo de aplicação da técnica para análise de dados qualitativos. Qualitas Revista Eletrônica, 16, 1-14. Retrieved from http://revista.uepb.edu.br/index.php/ qualitas/article/view/2113/1403 